\title{
Aggressive Coping Strategy in Situations of Social Conflict. An Attempt to Determine Personality Predictors
}

\section{Danuta BORECKA-BIERNAT•}

\begin{abstract}
The purpose of the study was to find personality predictors of aggressive coping strategies in adolescents in situations of social conflict. The empirical studies have been conducted in junior high schools on a sample of 893 adolescents (468 girls and 425 boys) aged 13-15. The study employed the following instruments: the Stress Assessment Questionnaire (Kwestionariusz Oceny Stresu, KOS) designed by D. Włodarczyk and K. Wrześniewski, The Rosenberg Self-Esteem Scale (SES), the Spielberger Three-Factor Inventory of Personality States and Traits (TISCO), as well as the Questionnaire for Analysis of Coping Strategies in Adolescents in Situations of Social Conflict (KSMK) designed by D. Borecka-Biernat. The results of the studies indicate that the assessment of a situation of conflict as a threat increases the implementation of the aggressive coping strategy in young people in situations of social conflict. Participation of adolescents in a situation in which the realization of their goals is under threat increases negative emotions. Aggression is a form of coping with anger experienced in a situation of social conflict.
\end{abstract}

Key words: youth; personality; aggression; conflict.

\section{Introduction}

Difficult situations are not exceptional occurrences in life; on the contrary, they are a regular occurrence since early childhood; challenges cannot be eliminated from life. In psychology, the notion of a "difficult situation" refers to actions that an individual performs in order to regulate their relationship with their environment. These actions are, however, disrupted by obstacles and inhibitions which prevent the individual's goal from being achieved. A normal course of the basic action is disturbed and the likelihood of completing

\footnotetext{
- Associate Professor of the University of Wrocław, PhD, Institute of Psychology, University of Wrocław, Wrocław, Poland, email: $\underline{\text { dbb@vp.pl }}$
} 
the task at the regular level decreases (Tomaszewski, 1982). Difficult situations do not constitute a uniform class, but are a varied category. They do not occur individually in an isolated form; multiple types of obstacles can arise in one situation (Tomaszewski, 1982), which means that different types of difficulties can overlap and become dependent on each other. An important category of difficult situations are social difficult situations, which threaten the values to which an individual subscribes and fulfillment of the individual's needs and aspirations (Tyszkowa, 1986).One type of difficult situations in social interactions are situations of social conflict, in which the goals of an individual are contradictory or incompatible with those of others, and realization of the individual's own goals is jeopardised. The word "conflict" is derived from Latin confligere, or conflictatio, which means clash, argument, discussion, fight, or collision of two or more processes or forces particular to living creatures. A collision might be the beginning of a fight. Many people wrongly associate conflict with direct physical and/or verbal aggression and accompanying hostility that increases the existing contradictions. This type of conflict is saturated with negative emotions. The majority of phenomena which may be described as conflicts take relatively mild forms of a short altercation, discussion, or debate (Olubiński, 1992).

Difficult social interactions marked with a sense of insecurity or risk to realization of one's aspirations or goals (or fulfilment of one's needs) are frequent in lives of adolescents. Every day, young people experience various problems connected with school, peers, or family life. Results of studies conducted by, among others, B. Lohman P. Jarvis (2000), R. Jaworski (2000), J. Różańska-Kowal (2004), and K. Polak (2010) have shown that during adolescence, young people usually consider conflicts with teachers, arguments with schoolmates, romantic partners, as well as parents and other relatives to be the most important sources of personal insecurity, unpleasant experiences, and intense stress.

The area that generates the most conflict between students and teachers are grades, tactless behaviour of the teacher, controlling pressure, and rigidity of requirements (Miłkowska, 2012). The main reasons for arguments with peers are taunts, betrayal, breach of trust, competition for grades, for the interest of the opposite sex, for position among the classmates, and sporting achievements (Różańska-Kowal, 2004; Polak, 2010). Most 
problems with mutual understanding between children and parents are caused by the change of young people's attitude towards their parents. Adolescents are less open towards their parents, while the parents frequently do not cope with the growing autonomy of their children and try to limit it (Obuchowska, 2010). Numerous conflicts with parents are caused by elements of daily life: differences in tastes, opinions - including those on learning performance - clothes, music, watching television, using computer, ways of spending free time, or returning home late in the evening (Jaworski, 2000).

Adolescence is a period in which young people experience various, often contradictory needs, and have to cope with inconsistent social expectations. Difficult situations encourage young people to take action oriented towards regaining the balance between expectations and abilities and/or improvement of their emotional state. Activity undertaken in a difficult situation is considered, in a specific situational context, as a coping strategy in a current difficult situation (Heszen-Niejodek, 2000). It is important, then, to examine how young people cope with conflicts which occur at school, in their relationships with peers, or in the family home. Numerous studies as well as casual observation indicate that the school environment, especially conflicts with teachers and classmates, are particularly stressful to adolescents. Empirical material in literature indicates that youth applies many different strategies of coping with school problems (Miłkowska, 2012). The most frequent strategy are behaviours that regulate emotions; fewer strategies mentioned by the participants of the studies were oriented towards working on the problem, an analysis of the situation and an attempt to change it. The strategies that the participants declared to apply in the context of coping with difficult situations at school included aggressive behaviour towards other people as well as objects. Classes and breaks are the times when the risk of young people relieving stress through aggressive coping methods is particularly high (Miłkowska, 2012; Różańska-Kowal, 2004). During classes, aggressive behaviour constitutes purposefully disrupting the lesson, damaging personal items placed on the teacher's desk, and expressing negative opinions on the teacher to friends and parents. Over 50\% of the respondents admitted that they engage in aggressive behaviour during breaks. Physical aggression is dominant (it consists of such behaviours as pushing, punching, and kicking), and the most 
frequent forms of verbal aggression include name-calling and mockery of another person or items that belong to them.

Conflict situations involving parents become, as the young person becomes an adolescent, an increasingly important source of tensions. The parent-child conflicts are a phenomenon occurring commonly during adolescence (Jaworski, 2000). Older adolescents want to emancipate from the parental control; their entire behaviour is a demand for expansion of rights. The obstacles and failures they face, as well as the expectations and limitations imposed on them by the parents provoke anger, expressed in "talking back", slamming doors, sometimes crying or direct attacks on people or objects (Lachowska, 2010).

The studied performed until now suggest that social conflict is connected with the issue of aggressive coping strategies in a specific situational context, whose aim is to avoid or minimize tensions, losses, and unfavourable outcomes. A question needs to be posed: why do young people in social conflict choose the strategy of aggressive reactions to difficulties? The answer to this question is facilitated by the concept of psychological mechanism of human behaviour in difficult situations, designed by M. Tyszkowa (1986). According to this author, an important role is played by the cognitive schemata determining the processes of perception of the external situation and the individual's emotional reflection of significance of that situation and of the course of their own action.

An individual's actions in a difficult situation is largely dependent on their assessment of their circumstances. A difficult situation that disrupts the routine activities, interferes with, endangers, or prevents realization of one's needs, may be assessed as harm/loss (referring to the sustained damage and losses connected with important objects), threat (referring to similar harm which is anticipated but have not yet occurred), or challenge (indicating the possibility to gain control over a difficult situation and benefit from it) (Włodarczyk, Wrześniewski, 2010).

An individual assessment of an event influences the person's decision on the possibility of activity (a remedial strategy) that will remove the causes of the difficult situation or at least lessen its impact (Heszen-Niejodek, 2000; Winstok, 2007). Thus, it can be said that the manner of coping with a specific situation and the choice of solutions to 
problems depend on the result of an individual's assessment of that situation in the category of harm/loss, threat, or challenge.

Data obtained by D. Domińska-Werbel (2014) indicate that adolescents adopting aggressive coping strategies in difficult social situations are characterized by a more frequent situational and dispositional cognitive appraisal of a difficult situation as one of harm/loss.

K. Kowalski, P. Crocker, and S. Hoar (2005) have determined that upon encountering a problem the individuals who assessed a difficult situation as threat applied mainly coping mechanisms based on emotions. Their entire effort was directed towards decreasing the unpleasant tension by means of violent emotional outbursts and/or activation of defensive mechanisms, without attempting to find an actual solution to the problem. Thus, individuals in who the situational and dispositional cognitive appraisal of a difficult situation as harm/loss or as threat is higher, display aggression, hyperactivity, or rebellious behaviour.

The perception of the world by an individual, their attitudes and expectations of themselves and of other people, as well as of the tasks they perform and the results of their own activity, determine the type of cognitive and emotional perception and interpretation of difficult situations. The collection of concepts and notions of oneself and expectations towards oneself - which constitute the structure of the self - plays an important role in an individual's behaviour in difficult situations (Kulas, 1986). From what is known, selfevaluation is an assessing and quantifying component of the structure of the self. Selfesteem is an assessment of one's self from the perspective of specific standards and requirements. It appears that an unfavourable, insufficiently organized and inadequate structure of the self is vulnerable in difficult situations, which causes a shift of the purpose of the individual's activity towards defending the self (Tyszkowa, 1986). As a result, goaloriented activity becomesdisorganized. A low (adequate, inadequate) or high (inadequate) self-esteem also has unfavourable influence on a young person's behaviour in difficult situations (Baumeister et al., 2003; Borecka-Biernat, 2006; Iskra, 2011; Ostrowsky, 2010; Turner-White, 2015). In difficult circumstances, an inadequate self-esteem leads to an increased sense of personal insecurity, an increase in negative emotions, and progressive disorganization of behaviour. A low assessment of oneself and of one's own abilities and 
efficiency in coping with various difficult situations facilitates the appearance of aggressive behaviours. In case of high (inadequate) self-esteem a tendency to release aggression can also be observed. As can be seen, both high and low self-esteem decrease resilience to difficult situations and efficiency, as well as hinders adaptation and ability to cope in the face of difficulties. Even a small obstacle or a low-level threat may provoke unbridled aggression in a person with a low or high (inadequate) self-esteem. This indicates that the level of self-esteem is a crucial factor influencing an individual's functioning in life, which is revealed in particular in situations of conflict in which an increased cognitive, motivational, and emotional involvement is necessary.

Conflict, which is an inherent element of social interactions, provokes a negative emotional tension (Deffenbacher, 1992). A continual, intense, and negative emotional stimulation becomes a basis for aggressive behaviour, irritation, and outbursts of rage (Gross, Halperin, Porat, 2013; Kossewska, 2008). The types of emotions that lead to aggressive behaviour are those that follow the sequence irritation-anger-rage. Their intensity determines the level and form of aggression. As noted by W. Łosiak (2009), anger and rage are related emotional states, connected by the similarity on the level of subjective experience, as well as by the connection with aggressive behaviours. It is worth mentioning that anger and rage are one of many possible negative emotional reactions, which appear in stressful situations, that are perceived as threat or loss/harm (Lazarus, 1986). According to L. Berkowitz (1992), emotions of rage and anger trigger activities aimed at recovery of the endangered or lost goals and lead to aggressive behaviours. D. Domińska-Werbel (2014) and J. Różańska-Kowal (2004) also conclude that the tendency to react with anger is connected with the impulse to fight and unwillingness to surrender in difficult situations.

The emotional sequence of fear-panic-anxiety, however, usually leads to withdrawal and escape (Borecka-Biernat, 2006; Borecka-Biernat, Ciuladiene, 2015; Łosiak, 2009). It appears that in natural conditions anger is an emotion that facilitates the fight response, while fear facilitates flight. Observations indicate, however, that if circumstances do not offer any escape route and if aggression is the only remaining solution, fear may cause an attack (Borecka-Biernat, 2006; Janowski, 2005; Nowosad, 2002). 
A study conducted by W. Sikorski (2015) has shown that young people with a high level of communication fear frequently applied aggressive coping mechanisms in situations of conflict in the classroom. Confronted with a conflict with peers, those students tend to "attack the problem" instead of attempting to solve or alleviate it, using physical violence against other people and objects, and/or manifest their hostile attitude towards others through accusatory, harmful, and humiliating comments. The results of the study indicate that aggression is an efficient strategy that allows to cope with fear experienced in difficult situations and conflicts, and it constitutes a reaction that facilitates hiding fear or diffusing the tension that it has caused.

To summarize, the concept of psychological mechanism of human behaviour in difficult situations, designed by M. Tyszkowa (1986), allows to describe certain personality determinants of the aggressive coping strategy applied by young people in situations of social conflict. Despite this, researchers should attempt to find determinants of the determinants of the aggressive coping strategy in social conflict applied by young people.

\section{Research problem and hypothesis}

The empirical studies were focused on the personality predictors of the aggressive coping strategy in youth in the situation of social conflict, with particular focus on the role of the type of cognitive appraisal of the situation of social conflict, level of self-esteem, as well as the intensity and the type of emotions. The studies were oriented towards answering the following research question:

1. What is the connection between the group of variables and the increased application of the aggressive coping strategy in a situation of conflict?

In this form, the research question allows to formulate a hypothesis, that will be verified through analysis of the results of the conducted empirical studies:

H.1 The aggressive coping strategy in youth in situation of social conflict is connected with assessment of the situation of conflict as a threat or harm/loss, as well as with a low or high level of general self-esteem and a high level of the negative emotions (anger, fear). 


\section{Method}

Participants and outline of the study. The study was conducted on a sample of 468 girls and 425 boys aged 13-15. In total, 893 students participated in the study. The participants were students of the first, second, and third year of junior high school. Voluntary and anonymous participation were ensured for all participants; the study was conducted in compliance with standards for psychological research. The basic criterion for selection of the participants was age. The influence of age on the choice of aggressive coping strategy in a situation of social conflict was studied on a sample of participants aged 13 to 15 (early adolescence). As a time of transition from childhood to adulthood - also described as the period of rebellion and resistance - adolescence is an important stage in an individual's life. It is during adolescence that many biological, psychological, mental, motivational, and social changes occur, which causes numerous difficulties connected with adjusting a young person's behaviour to accommodate new situations, tasks, and social roles (Czerwińska-Jasiewicz, 2003).

\section{Research tools}

The following instruments were applied in the study:

The Stress Assessment Questionnaire (Kwestionariusz Oceny Stresu, KOS) designed by D. Włodarczyk and K. Wrześniewski (2010), comprised of 35 adjective phrases describing stressful situations. The questionnaire consists of two versions containing the same sets of the adjective phrases but different instructions for the participants. In version A (measurement of the situational assessment of stress) the participants are asked to indicate a specific difficult situation that occurred the previous week (the present study used a situation of social conflict). Version B (measurement of dispositional assessment of stress) contains an instruction in which the participants are asked to mark the degree to which the provided adjectives are consistent with what they most frequently experience in difficult situations (the present study used a situation of social conflict). KOS consists of 6 subscales which indicate specific types of stress assessment, including state-anxiety, traitanxiety, trait-harm/loss, state-challenge, and trait-challenge. The "anxiety", "challenge", and "harm/loss" subscales consist of 10, 6, and 4 items respectively. The questionnaire is 
sufficiently accurate and reliable (Cronbach's $\alpha$ for version A was .76-.90, and for version B $.79-.90)$.

The Rosenberg Self-Esteem Scale (SES), adapted by M. Łaguna, K. Lachowicz-Tabaczek and I. Dzwonkowska (2007) allows to calculate the level of overall (global) self-worth both in adolescents and adults. SES consists of 10 diagnostic descriptive statements referring to the participant via which they are able to outline their self-worth. A high result indicates a high level of global self-worth. The scale is characterized by accuracy (Cronbach's $\alpha$ was .81.83) and diagnostic relevance.

The Spielberger Three-Factor Inventory of Personality States and Traits (TISCO) is a Polish adaptation of the American State-Trait Personality Inventory (STPI) designed by C. Spielberger (Wrześniewski, 1991). TISCO consists of two independent parts. Part one (SPI) measures anxiety, anger, and curiosity interpreted as emotional states experiences in a specific moment. Part two (TPI) is applied to study the same emotions interpreted as personality traits. The Inventory contains 6 subscales: state-anxiety, trait-anxiety, stateanger, trait-anger, state-curiosity and trait-curiosity. Each subscale consists of 10 short, simple statements referring to subjective emotions of the participant. The relevance and accuracy of TISCO are sufficient and close to the original version of the instrument (STPI).

The KSMK Questionnaire designed by D. Borecka-Biernat (2012) examines coping strategies in situations of social conflict applied by adolescent youth. It is comprised of descriptions of 33 situations of social conflict. Each description is accompanied by four types of coping behaviour in a situation of social conflict: aggressive coping ("A"), coping by avoidance ("U"), coping by submission ("UI"), and task-oriented coping ("Z"). The results are obtained separately for each scale, by summing up the behaviours marked by the participant in the 33 situations. The aggressive coping scale ("A") for youth in situations of social conflict was used for the purpose of the study. The Questionnaire is characterized by sufficient accuracy (Cronbach's $\alpha$ was around or above .07) and diagnostic relevance.

\section{Analysis of the results}

Due to a large number of independent variables hierarchical regression was applied and the method of backward elimination was used (criterion: probability-of-f-to-remove 
$>=.100$ ). In this method, all potential predictors are introduced into the model and the irrelevant variables are subsequently removed, after which the model is recalculated until the final version is obtained (Bedyńska, Książek, 2012). The regression analysis was performed on the results obtained from the entire studied group of young people; separate regression analyses were also performed after dividing the participants by gender. The results are presented in Table 1.

Table 1. Multiple stepwise regression for the result of the Aggression scale (A) in Questionnaire for Coping Strategies in Adolescents in Situations of Social Conflict (KSMK) in relation to the following scales: the Stress Assessment Questionnaire (KOS), the SelfEsteem Scale (SES), the Three-Factor Inventory of Personality States and Traits (TISCO): results for the entire group: $(\mathrm{N}=893)$; results for girls $(\mathrm{N}=468)$ and boys $(\mathrm{N}=425)$

\begin{tabular}{|c|c|c|c|c|c|c|}
\hline Participants & Variable & Beta & B & $\begin{array}{l}\text { Standard } \\
\text { error. B }\end{array}$ & $\mathrm{t}$ & $\begin{array}{l}\text { Level } \\
\mathrm{p}<\end{array}$ \\
\hline \multicolumn{7}{|l|}{ Total } \\
\hline & State-threat & .08 & .06 & .02 & 2.58 & .010 \\
\hline & State-anger & .19 & .13 & .03 & 4.44 & $<.001$ \\
\hline & State- anxiety & -.08 & -.12 & .06 & -2.08 & .040 \\
\hline & Trait-anger & .31 & .23 & .03 & 7.34 & $<.001$ \\
\hline & Trait- anxiety & -.09 & -.08 & .04 & -2.29 & .020 \\
\hline & Trait- & -.09 & -.09 & .03 & -2.74 & .006 \\
\hline & curiosity & & 3.64 & 1.39 & 2.63 & .009 \\
\hline \multicolumn{7}{|c|}{ Free term } \\
\hline \multirow{4}{*}{\multicolumn{7}{|c|}{$\begin{array}{l}\text { Multiple correlation coefficient: } \mathrm{R}=.38 \text {. } \\
\text { Coefficient of multiple determination: } \mathrm{R}^{2}=.14 \\
\text { Significance of the equation: } \mathrm{F}(6,886)=24.59 ; \mathrm{p}<.00001 \\
\text { Standard estimation error: } 4.32\end{array}$}} \\
\hline & & & & & & \\
\hline & & & & & & \\
\hline & & & & & & \\
\hline \multicolumn{7}{|l|}{ Girls } \\
\hline & e-threat & .12 & .08 & .03 & 2.60 & .010 \\
\hline & e-anger & .23 & .17 & .04 & 4.01 & $<.001$ \\
\hline & - anxiety & -.17 & -.24 & .07 & -3.21 & .001 \\
\hline & t-anger & .34 & .25 & .04 & 5.72 & $<.001$ \\
\hline & t-anxiety & -.14 & -.13 & .05 & -2.49 & .013 \\
\hline & t-curiosity & -.10 & -.09 & .04 & -2.09 & .037 \\
\hline & term & & 5.75 & 1.84 & 3.12 & .002 \\
\hline
\end{tabular}

Multiple correlation coefficient: $\mathrm{R}=.40$

Coefficient of multiple determination: $\mathrm{R}^{2}=.16$

Significance of the equation: $F(6,461)=14.78 ; p<.000001$

Standard estimation error: 4.28 


\begin{tabular}{lllllll}
\cline { 1 - 1 } Boys & & & & & \\
& State-anger & .15 & .11 & .04 & 2.91 & .004 \\
& State-curiosity & -.11 & -.11 & .05 & -2.38 & .020 \\
& Trait-anger & .26 & .20 & .04 & 5.05 & $<.001$ \\
& Free term & & 2.20 & 1.46 & 1,51 & .132
\end{tabular}

Multiple correlation coefficient: $\mathrm{R}=.37$

Coefficient of multiple determination: $\mathrm{R}^{2}=.14$

Significance of the equation: $F(3,421)=22.44 ; \mathrm{p}<0.000001$

Standard estimation error: 4.31

The first regression analysis was performed on the results obtained from the entire studied sample, regardless of gender. As can be seen in Table 1, the following six variables had significant influence on the aggressive coping strategy in youth in situations of social conflict: situational assessment of the conflict as threat, anger as an emotional state, fear as an emotional state, anger as a personality trait, fear as a personality trait, and curiosity as a personality trait. These predictors explain $14 \%$ of variance in application of the discussed strategy, and the described model is well adjusted $(F(6.886)=24.59 ; \mathrm{p}<.00001]$. The remaining predictors were not significant determinants of the frequency with which young people apply the aggressive coping strategy in situations of social conflict. The beta slope indicates that a higher level of situational assessment of the conflict as threat, a higher level of anger as an emotional state, a lower level of fear as an emotional state, a higher level of acquired tendency to react with anger, a lower level of acquired tendency to react with fear, as well as a lower level of tendency to react with curiosity have influence on the increase in frequency of incidence of aggressive coping strategy in youth in situations of social conflict.

Separate regression analyses were conducted after dividing the participants by gender (compare: Table 1). Stepwise regression analysis has shown that among thirteen independent variables introduced in the regression model, six were of low significance for explaining the use of aggressive coping strategy by girls in a situation of social conflict. The remaining monitored indicators did not show statistically significant correlations with aggressive coping strategy in girls. The calculations indicate that situational assessment of conflict as threat, anger as an emotional state, fear as an emotional state, anger as a personality trait, fear as a personality trait, and curiosity as a personality trait play an important determining role for application of the aggressive coping strategy by girls. The 
enumerated predictors explain 15\% of variance in application of the discussed strategy by girls, and the described model is well adjusted [ $F(6.451)=14.78 ; \mathrm{p}<.000001]$. It is evident that the more a current conflict situation is assessed as threat, the higher the level of anger as an emotional state and of the acquired tendency to react with fear, and the lower the level of fear as an emotional state, of acquired tendency to react with fear, and of tendency to react with curiosity, the more frequently the studied girls apply the aggressive strategy.

Another examined problem was which group of personality variables has influence on the level of aggressive coping strategy in boys in situation of social conflict. The following three independent variable proved significant in the regression equation: anger as an emotional state, curiosity as an emotional state, and anger as a personality trait. The discussed model proved to be well adjusted to the data $[F(3.421)=22.44 ; p<.000001]$ and explained $13 \%$ of the variance of the dependent variable. The standardized beta coefficients revealed that the increase of the use of aggressive strategy in boys in the context of social conflict is influenced by a higher level of anger as an emotional state and of the acquired tendency to react with anger, as well as a lower level of fear as an emotional state.

To summarize the conducted regression analysis, the assumed personality variables have partially confirmed the validity of the formulated hypothesis H.1.

\section{Summary of the results}

An analysis of the results has revealed that a situational assessment determining classification of a conflict as threat is connected with aggressive coping strategy in youth, particularly in girls involved in a situation of social conflict. It can be suspected that a situational assessment of a conflict as threat increases the application of aggressive coping strategy by young people in situations of social conflict. It should be concluded that an adolescent who has found themselves in a situation of social conflict which they assess as threat will apply aggressive strategy in order to cope with that situation (Ratajczak, 2000). This tendency appears to be consistent with the statement by L. Berkowitz (1992) according to which aggression is generated as a result of perceived threat, a conviction that one is an object of intentional, wrongful treatment, and violation of an individual's sense of self-worth. 
Statistical analyses of the results have not indicates a dependence between the level of self-esteem and aggressive coping strategy in adolescents. It may be caused by a large number of variables introduced in the model causing other variables to prove more statistically significant for the aggressive coping strategy than the global assessment of selfworth. Moreover, an explanation should be sought for the obtained results for the global assessment of the self (as measured by the SES questionnaire) - that is, without referring to the sense of self-worth of individual participants which might significantly conceal the full image of the overall self-esteem of the participants of the study. Self-worth, studied with the Rosenberg questionnaire adapted by M. Łaguna, K. Lachowicz-Tabaczek, and I. Dzwonkowska (2007), is the attitude of an individual to their Self, a type of a global assessment of oneself. Therefore, the assessment of self in particular dimensions - such as intellectual capacity, social skills, physical fitness, or resourcefulness - correlates with the self-esteem, but it is not neither empirically, nor conceptually identified with it (Marsch, 1996, as cited by Łaguna, Lachowicz-Tabaczek, Dzwonkowska, 2007).

After conducting the analysis it has been determined that aggressive coping strategy in situations of social conflict is influenced mainly by anger as an emotional state experienced in a specific moment, as well as the acquired tendency to react with anger. It can be suspected that with the increase of the level of the state-anger and trait-anger the aggressive coping strategy will be applied more frequently by young people (both overall and with regard to gender) in a situation of social conflict. A similar result was obtained in the studies conducted by D. Borecka-Biernat and G. Ciudalene (2015), D. Domińska-Werbel (2014), and J. Kossewska (2008). Moreover, a significant negative relationship was noted between the aggressive coping strategy and fear as a current emotional state, fear as a personality trait, as well as curiosity as an emotional state in a specific moment and curiosity as a relatively permanent personality trait. It can be expected that a more frequent application of the aggressive coping strategy by youth in situations of social conflict is connected with a proportionately lower level of fear (as state or trait) and curiosity (as state or trait) (Domińska-Werbel, 2014). It should be noted that the attempt to find determinants of the aggressive coping strategy in situation of social conflict in fear as a state and fear as a trait was unsuccessful. It can be suspected that the high level of fear in adolescents in 
situations of social conflict causes forms of indirect aggressive behaviour, such as mistrust and hostile attitude towards the environment (Leary, Kowalski, 2001; NitendelBujakowska, 2001). It is worth noting that a situation of social conflict, perceived as threat, does not generate positive emotions (such as curiosity) which facilitate an active approach to coping with difficulties (Łosiak, 2009). This result seems to be consistent with the conclusion formulated by M. Tyszkowa (1986), according to which the structure of an individual's personality and their traits decide whether the emotional tension provoked by a difficult situation is interpreted as in terms of information-compensation (in relation to the purpose of the activity) or as a signal of a personal threat.

To summarize the obtained result, it can be concluded that a young person's cognitive reaction to a situation of social conflict may have influence on their choice of coping strategy. If the situation of social conflict is perceived as a threat, an adolescent is more likely to apply an aggressive strategy. It should not be forgotten that an individual's reaction to social conflict is emotional, and they may experience anger. It should be, therefore, suspected that an assessment of a situation of social conflict as a threat may provoke aggression. This strategy facilitates the release of anger experienced by young people in circumstances which endanger the realization of their aspirations. The aggressive strategy is primarily a form of coping with anger experienced during conflict. It should also be noted that, together with the increase of anger (as a tendency) in adolescents in situations of social conflict, the aggressive coping strategy is also increased. It suggests that an adolescent assessing a social conflict situation in terms of threat will apply aggressive coping methods which may, even temporarily, free them from the unpleasant emotional tension, and which are not oriented towards finding a solution and overcoming the difficulties.

Finally, it is difficult to ignore that fact that the selected personality variables are not strong predictors of the aggressive coping strategy in youth in situations of social conflict; this means that there may exist numerous other variables which co-determine the level of aggressive coping strategy in youth in situations of social conflict. The area that appears to be worthy of further scientific exploration is conducting research with reference to the genetic (related to the temperament) nature of an individual's functioning in conflict and to the influence of the family environment on the ability to overcome the biological 
determinants and become a person capable of proactively coping with conflict. It should be considered that the results of these studies may become the beginning of exploration of those areas within the problem of the determinants of the aggressive coping strategy in adolescents in situations of social conflict which have, until now, been neglected.

\section{References}

Baumeister, R., Campbell, J., Krueger, J., Vohs, K. (2003). Does high self-esteem causa better performance, interpersonal success, happiness, Or healthier lifestyles? Psychological Science in the Public Interest , 4 (1) 1-44.

Bedyńska, S., Książek, M. (2012). Praktyczny przewodnik wykorzystania modeli regresji oraz równań strukturalnych. Warszawa: Akademickie Sedno.

Berkowitz, L. (1992). O powstawaniu i regulowaniu gniewu i agresji. Nowiny Psychologiczne, 1-2, 87-105.

Borecka-Biernat, D. (2006). Strategie radzenia sobie młodzieży $w$ trudnych sytuacjach społecznych. Psychospołeczne uwarunkowania. Wrocław: Wyd. U.Wr.

Borecka-Biernat, D. (2012). Kwestionariusz strategii radzenia sobie młodzieży w sytuacji konfliktu społecznego. Psychologia Wychowawcza, 1-2, 86-118.

Borecka-Biernat, D., Ciuladiene, G. (2015). The Role of Anger, Fear and Curiosity in Various Conflict Resolution Strategies. Culture and Education, 4 (110), 9-29.

Czerwińska-Jasiewicz, M. (2003). Społeczno-kulturowe podejście do dorastania. In: A.Jurkowski (Eds.), $Z$ Zagadnień wspótczesnej psychologii wychowawczej. (pp.208-226). Warszawa: Wyd. Instytutu Psychologii PAN.

Deffenbacher, J. (1992). Trait anger: Theory, findings and implications. In C.Spielberger, J.Butcher (Eds.), Advances in personality assessment .(pp.177-201). Hillsdale, NJ: Lawrence Erlbaum Associates.

Domińska-Werbel, D. (2014). Psychologiczne uwarunkowania strategii radzenia sobie młodzieży gimnazjalnej $w$ trudnych sytuacjach społecznych. Legnica: WPWSZ.

Dzwonkowska I., Lachowicz-Tabaczek, K., Łaguna, M. (2007). Skala samooceny SES Morrisa Rosenbergapolska adaptacja metody. Psychologia Społeczna, 2, 164-176.

Gross, J., Halperin E., Porat R. (2013). Emotion regulation in intractable conflicts. Current Directions in Psychological Science, 22 (6), 423-429.

Heszen-Niejodek, I. (2000). Teoria stresu psychologicznego i radzenia sobie. In: J.Strelau (Eds.), Psychologia. Vol.3. (pp. 465-492). Gdańsk: GWP.

Iskra, J. (2011). Wybrane osobowościowe uwarunkowania trudności doświadczanych przez studentów pierwszego roku. In: D.Borecka-Biernat (Eds.), Zaburzenia w zachowaniu dzieci i młodzieży w kontekście trudnych sytuacji szkolnych i pozaszkolnych. (pp. 99-119).Kraków: Oficyna Wydawnicza Impuls.

Janowski, M. (2005). Radzenie sobie z lękiem, smutkiem i złością. Chowanna, R. 48, t. 1, 92-107.

Jaworski, R. (2000). Konflikt pokoleń w okresie adolescencji. Psychologiczne aspekty radzenia sobie ze stresem. In: R.Jaworski, A.Wielgus, J.Łukjaniuk, (Eds.), Problemy człowiek w świecie psychologii. (pp.2754). Płock: Wyd. Naukowe NOVUM.

Kossewska, J.(2008). Zasoby osobowe a agresja interpersonalna u młodzieży gimnazjalnej. In: H. WronaPolańska (Eds.), Zdrowie - stres - choroba w wymiarze psychologicznym. (pp.145-159). Kraków: Wyd. Impuls, 145-159. 
Kowalski, K., Crocker, P., Hoar, S. (2005). Adolescent's control beliefs and doping with stress in sport. International Journal of Sport Psychology , 36(4), 257-272.

Kulas, H. (1986), Samoocena młodzieży. Warszawa: WSiP.

Lachowska, B. (2010). Style rozwiązywania konfliktów i ich efekty w relacji miedzy rodzicami i adolescentamiprezentacja narzędzi pomiaru. In: D. Borecka-Biernat (Eds.), Sytuacje konfliktu w środowisku rodzinnym, szkolnym i rówieśniczy. Jak sobie radzq z nimi dzieci i młodzież ? (pp.180-206). Warszawa: Wyd. Difin.

Lazarus, R. (1986), Paradygmat stresu i radzenia sobie. Nowiny Psychologiczne, 3-4, 2-40.

Leary, M., Kowalski, R. (2001). Lęk społeczny. Gdańsk: GWP.

Lohman, B., Jarvis, P. (2000). Adolescent stressors, coping strategies, and psychological health studied in the family context. Journal of Youth and Adolescence, 29,15-43.

Łosiak, W. (2009), Stres i emocje w naszym życiu. Warszawa: Wydawnictwa Akademickie i Profesjonalne.

Miłkowska, G. (2012). Agresja w okresie dorastania-charakterystyka, przejawy, przeciwdziałanie. In: Z. Izdebski (Eds.), Zagrożenia okresu dorastania. (pp.91-110). Zielona Góra: Wyd. U.Z.

Nitendel-Bujakowa, E. (2001), Lęki szkolne jako wyznacznik funkcjonowania dziecka. Problemy poradnictwa psychologiczno-pedagogicznego, 1, 15-37.

Nowosad, D. (2002). Lęk i agresja w zachowaniu młodzieży szkół licealnych. Kwartalnik Pedagogiczny ,2, 131142.

Obuchowska, I. (2010). Adolescencja. In: B.Harwas-Napierała, J.Trempała (Eds.), Psychologia rozwoju człowieka. Charakterystyka okresów życia człowieka. Vol. 2 (pp. 163-201). Warszawa: PWN.

Olubiński, A. (1992). Konflikty rodzice-dzieci. Dramat czy szansa. Toruń: Wyd. Adam Marszałek.

Ostrowsky, M. (2010). Are violent people more likely to have low self-esteem or high self--esteem? Aggression and Violent Behavior, 15, 69-75.

Polak, K. (2010). Uczeń w sytuacji konfliktów szkolnych. In: D.Borecka-Biernat (Eds.), Sytuacje konfliktowe w środowisku rodzinnym, szkolnym i rówieśniczym. (pp.23-40).Warszawa: Wyd.Difin.

Ratajczak, Z. (2000). Stres-radzenie sobie-koszty psychologiczne. In: I.Heszen-Niejodek, Z.Ratajczak (Eds.), Człowiek w sytuacji stresu. Problemy teoretyczne i metodologiczne. (pp.65-87).Katowice: Wyd. UŚ.

Różańska-Kowal, J. (2004). Szkoła jako główne źródło stresu młodzieży w wieku dorastania. Kwartalnik Pedagogiczny, 3, 203-214.

Sikorski, W. (2015) Lęk komunikacyjny u uczniów a ich sposoby reagowania w sytuacjach konfliktu w klasie szkolnej. In: D.Borecka-Biernat, M.Cywińska (Eds.), Konflikt społeczny w perspektywie socjologicznej $i$ pedagogiczno-psychologicznej.(pp.126-146). Warszawa: Wyd. Difin.

Tomaszewski, T. (1984). Ślady i wzorce. Warszawa: WSiP.

Turner, A., White B. (2015), Contingent on contingencies: Connections between anger rumination, selfesteem, and agression. Personality and Individual Differences, 82, 199-202.

Tyszkowa, M. (1986). Zachowanie się dzieci w sytuacjach trudnych. Warszawa: PWN.

Winstok, Z. (2007). Perceptions, emotions, and behavioral decisions in conflicts that escalate to violence. Motivation and Emotion, 31 (2), 125-136.

Włodarczyk, D., Wrześniewski K. (2010). Kwestionariusz Oceny Stresu (KOS). Przegląd Psychologiczny, 4, 479496.

Wrześniewski, K. (1991). Trójczynnikowy inwentarz stanów i cech osobowości. Przegląd Lekarski, 2, 222-225. 